\title{
Differences in Family Relations and Mental Health according to Marital Status and Gender in Old Age
}

\author{
노년기 결혼지위와 성별에 따른 \\ 가족관계와 정신건강의 차이 \\ Yun-Jeong Kim ${ }^{1}$, Sang-Jin Lee ${ }^{2}$ \\ 김윤정 ${ }^{1}$, 이상진 2 \\ ${ }^{1}$ Professor, Dept. of Health, Counselling and Welfare, Hanseo Uinversity, Republic of Korea, \\ twoyun21@hanmail.net \\ ${ }^{2}$ Team Manager, Chungcheongnam-do Public Agency for Social Service, Republic of Korea, \\ welfare-i@hanmail.net
}

Corresponding author: Sang-Jin Lee

\begin{abstract}
The purpose of this study was to investigate on the effects of marital status and gender in old age on family relationships (family relationship satisfaction and family conflict) and mental health (life satisfaction, depression). Furthermore, this study is also aimed to reveal how these influences change over time. Among the data from the Korea Welfare Panel 2014 (9th), the data of 4,048 elderly people aged 60 or older were used, and reliability analysis, frequency analysis, and two-way ANOVA were applied using SPSS 21.0 ver. First, marriage status in old age had a significant effect on both family relations and mental health in 2014 and 2019. Married elders had higher family relationship satisfaction and life satisfaction and lower depression than divorced elders. However, the family conflict was higher. Second, the interaction between marriage status and gender had a significant effect on family relationship satisfaction, family conflict, life satisfaction and depression in 2014, family relationship satisfaction and life satisfaction in 2019. Excluding family conflict, among the four groups according to marital status and gender, divorced male elders had the lowest family relationship satisfaction and life satisfaction, and the highest depression. Third, it can be seen that the effect of marital status on family relations and mental health is decreasing with the passage of time. In other words, in 2014, the interaction effect between marriage status and gender was significant in all four areas: family relationship satisfaction, family conflict, life satisfaction, and depression, but in 2019, it had a significant effect only on family relationship satisfaction and life satisfaction.
\end{abstract}

Keywords: Divorce in Old Age, Marital Status, Gender, Family Relationship, Mental Health

요약: 본 연구의 목적은 노년기 결혼지위와 성별이 가족관계(가족관계만족도와 가족갈등)와 정신건강(삶의 만족도, 우울감)에 미치는 영향을 파악하는데 연구의 목적을 두었다. 또한, 이러한 영향력이 시간경과에 따라 어떻게 변화하는지 밝히고자 하였다. 한국복지패널 2014년도 (9차) 데이터 기준으로 60세 이상 노인 4,048명의 데이터를 활용하였으며, SPSS 21.0 ver.을 사용하여 신뢰도분석, 빈도분석, 이원분산분석을 적용하였다. 첫째, 노년기 결혼지위는

Received: March 25, 2021; 1st Review Result: May 08, 2021; 2nd Review Result: June 17, 2021

Accepted: July 31, 2021 
2014년도와 2019년도 가족관계와 정신건강에 모두 유의한 영향을 미쳤다. 기혼노인이 이혼노인에 비해 가족관계만족도와 삶의 만족도가 높고, 우울감이 낮았다. 그러나 가족갈등은 더 높았다. 둘째, 결혼지위와 성별이 상호작용하여 2014년도 가족관계만족도와 가족갈등, 삶의 만족도와 우울감, 2019년도 가족관계만족도와 삶의 만족도에 유의한 영향을 미쳤다. 가족갈등을 제외하고, 결혼지위와 성별에 따른 4집단 중 이혼남성노인의 가족관계만족도와 삶의 만족도가 가장 낮고, 우울감은 가장 높았다. 셋째, 시간경과에 따라서 결혼지위와 성별이 가족관계 및 정신건강에 미치는 영향은 감소하고 있다고 볼 수 있다. 즉, 2014년도에는 가족관계만족도, 가족갈등, 삶의 만족도, 우울감의 4개 영역에서 모두 결혼지위와 성별의 상호작용효과가 유의하였으나, 2019년도에는 가족관계만족도와 삶의 만족도에만 유의한 영향을 미쳤다.

핵심어: 노년기 이혼, 결혼지위, 성별, 가족관계, 정신건강, 시간경과에 따른 변화

\section{1. 서론}

노인인구의 증가와 더불어 우리 사회에서는 노년기 삶에 대한 관심이 상당히 높다. 그런데 이러한 관심만큼 노년기의 삶의 질이 높은가는 의문이다. 노년기는 직업 생활에서의 은퇴와 신체적인 노화, 심리적 어려움, 사회망의 축소, 경제적인 빈곤 등 삶의 전반에서 어려움을 겪게 되나, 반면 배우자에 대한 심리적 정서적 의존도는 높은 시기이다[1]. 특히 노년기 은퇴로 가정에서 시간을 많이 보내게 되는 노부부는 친밀감과 더불어 갈등을 겪을 시간도 증가하게 되고[2], 성인기와 중년기 동안 쌓은 부부 간의 갈등이 다시 드러나기도 하면서[3], 두 사람의 관계는 악화하기도 한다[4]. 또한 확대가족 속에서의 조부모로서의 역할개념이 줄어들면서 노부부로의 역할은 증가하고, 역할 변경, 역할 분담 사이에서의 갈등을 겪기도 한다[5].

이에 따라 노년기 이혼이 증가하고 있으나, 여전히 이혼자는 기혼자에 비해 가족관계와 정신건강이 부정적이다. 기혼자에 비해 이혼자는 가족관계가 나쁘고 우울감이 높았다[1] [6][7]. 이혼은 이혼 그 자체로도 정신건강에 부정적인 영향을 미치지만, 이혼 후에 살아가는 삶에서 발생하는 또 다른 스트레스가 정신건강에 부차적인 영향을 미치기도 한다. 이혼으로 야기될 수 있는 우울감은 그 우울감 자체로 이혼의 결과인 동시에 이혼자의 건강에 나쁜 영향을 주는 요인이라는 것이다[8].

노년기 가족관계와 정신건강에 영향을 미치는 또 하나의 중요한 사회인구학적 변수는 바로 성별차이다. 그런데 선행연구를 고찰해보면, 가족관계와 정신건강에서의 성별차이는 상반된 연구결과가 존재한다. 일반적으로 여성노인이 남성노인에 비해 결혼만족도가 낮고, 부부갈등이 높으며, 우울감이 높다[1]. 물론, 이혼남성도 가족관계에서의 어려움을 겪고[9], 이혼 후 남성이 여성에 비해 신체건강이 나쁘다는 연구결과[8][10]도 있다.

이처럼 노년기 결혼지위와 성별에 따라 가족관계와 정신건강에서의 차이가 있다면, 결혼지위와 성별이 상호작용하면서도 가족관계와 정신건강에도 영향을 미칠 것이다. 이는 결혼의 효과가 남성과 여성 중 누구에게 좀 더 유리하게 작용하는가에 대한 의문과 같은 맥락이다. 남성노인은 여성노인에 비해 전통적 성역할 고정관념이 높고, 노년기에 일상생활에서 아내에게 의존하는 경향이 크기 때문에, 이혼의 부정적인 영향은 남성에게 더 심각할 것이고, 같은 이유로 기혼의 긍정적인 영향은 남성에게 더 클 것이고[1], 
이혼의 긍정적인 영향은 여성에게 더 클 수 있다는 것이다. 그러나, 실증연구에서 이 변수들을 동시에 고려한 연구는 부족하다. 기혼남성의 자살률은 인구 10 만 명당 35 명 정도인데 비해, 비기혼남성(이혼, 사별, 비혼 등)의 자살률은 100 명을 훨씬 더 넘고, 여성은 남성보다 자살률 수준은 전반적으로 낮지만 비기혼여성의 자살률이 기혼여성에 비해 2 배 이상 높았다는 연구[11]가 있다. 또한 이민아[1]는 남성노인의 경우 배우자가 있는 노인이, 사별이나 이혼, 별거 등의 결혼해체를 경험한 남성이 우울감이 낮으나, 여성의 경우에는 배우자가 있는 여성과 사별한 여성 간의 차이가 없었다고 밝혔다. 그런데, 박세진[11]은 노인에 초점을 두지 않았고, 이민아[1]는 우울감만을 다루었다.

한편, 본 연구에서 또 하나 주목을 하는 것은 바로 노년기 결혼지위와 성별에 따른 가족관계와 정신건강에서의 차이가, 시간이 경과한 뒤에도 여전한가? 이다. Gray 등[12]은 종단적 연구설계를 하여서 분석한 결과, 시간이 경과함에 따라 여성이 남성에 비해 신체 건강이 나빠진다고 하였고, $\operatorname{Kim}[7]$ 은 패널데이터를 활용하여, 기혼노인이 이혼노인에 비해 가족관계와 정신건강(우울감과 삶의 만족도)이 더 좋지만, 5년이라는 시간이 경과한 뒤에는 기혼노인과 이혼노인 간의 차이가 줄어들었다고 밝혔다. 김윤정[13]은 이혼남성노인의 가족관계와 삶의 만족도가 이혼여성노인에 비해 더 나빴으나, 시간이 경과함에 따라 성에 따른 차이가 유의미하지 않았다고 밝혔다. 따라서 이 연구들을 종합해보면, 노년기 결혼지위와 성별에 따른 가족관계와 정신건강의 차이는 시간경과에 따라 줄어들 것으로 예측이 되나, 결혼지위와 성별에 따른 차이가 시간경과에 따라서 어떻게 변하였는가를 밝힌 연구는 없었다.

이에 본 연구의 목적은 노년기 결혼지위와 성별이 가족관계(가족관계만족도와 가족갈등)와 정신건강(삶의 만족도, 우울감)에 미치는 영향을 파악하는데 연구의 목적을 두었다. 또한, 이러한 영향력이 시간경과에 따라 어떻게 변화하는지 밝히고자 하였다. 구체적으로 첫째, 2014년도 노인의 결혼지위 및 성별이 상호작용하여 가족관계와 정신건강에 영향을 미치는가? 둘째, 2019년도 노인의 결혼지위와 성별이 상호작용하여 가족관계와 정신건강에 영향을 미치는가?

\section{2. 연구방법}

\section{1 연구설계}

본 연구는 노년기 결혼지위와 성별이 상호작용하여 가족관계와 정신건강에 미치는 영향을 파악하기 위해 한국복지패널[14]의 2014년도(9차)와 2019년(14차) 데이터를 이용한 상관관계 연구이다.

\section{2 연구대상}

본 연구에서는 한국복지패널[14]의 ' 1 14차 복지패널조사 결합데이터'를 사용하였다. 2014년도 기준으로 만 60세 이상인 노인 중 '기혼'인 노인과 '이혼'인 노인 4,048명의 데이터를 분석에서 활용하였고, 2014년도와 2019년도의 데이터는 동일한 노인이다.

본 연구대상인 남녀노인 4,048 명 중 남성노인은 2,160 명 $(53.4 \%)$, 여성노인은 1,888 명 $(46.6 \%)$ 이다. 연령은 평균 76.12 세였고, 초등졸 이하가 $51.9 \%$, 중·고등졸이 $39.7 \%$, 대졸이상이 $8.3 \%$ 였다. 종교가 있는 노인이 $57.8 \%$, 종교가 없는 노인이 $42.2 \%$ 였고, 
대도시에 거주하는 경우가 $38.1 \%$, 중소도시에 거주하는 경우가 $34.6 \%$, 군이하 지역에 거주하는 경우가 $27.2 \%$ 였다.

\section{3 자료수집절차}

본 연구에서 사용한 한국복지패널[14]의 데이터는 매년 조사원이 직접 조사대상 패널가구를 방문하여 응답자의 응답을 조사원이 기록하는 방식으로 설문조사를 한다. 한국복지패널의 대상은 가구단위 조사로써, 층화이중추출법을 이용하여 최종 7,000 패널가구를 선정하였고, 매년 동일한 가구에서 설문조사를 실시한다. 또한, 한국복지패널 [14]에서는 매년 생명윤리위원회로부터 ‘승인’을 받고 설문조사를 시작한다.

\section{4 측정도구}

본 연구에서는 한국패널데이터 중에서 가족관계변수(가족관계만족도와 가족갈등)와 정신건강변수(삶의 만족도, 우울감)를 선별하여 분석에 사용하였다. 가족관계변수 중 가족관계만족도는 7점 리커트형 단일문항이었다. 가족갈등은 가족 간의 의견충돌이나 서로 비난함 등의 5문항, 5점 리커트형이다. 척도의 신뢰도인 Cronbach's alpha 값은 2014년도에는 $.80,2019$ 년도에는 .81이었다. 정신건강변수 중 삶의 만족도는 5점 리커트형(“매우 불만족”(1점)부터 “매우 만족”(5점)) 단일문항이었다. 우울감은 CES$\mathrm{D}$ (Center for Epidemiologic Studies-Depression Scale)를 사용하였다. 11문항, 4점 리커트형 척도이고[14], 11 문항의 평균값을 분석에 사용하였다. 척도의 신뢰도인 Cronbach's alpha 값은 2014 년도에는 $.85, \quad 2019$ 년도에는 .87이었다. 가족관계만족도와 삶의 만족도는 단일문항으로 신뢰도를 산출하지 않았다.

\section{5 통계분석방법}

본 연구의 목적을 달성하기 위해 SPSS 21.0 ver. 을 사용하여, 빈도분석, 신뢰도분석, 이원분산분석을 적용하였다.

\section{3. 연구결과 및 해석}

\subsection{4년도 노인의 결혼지위와 성별이 가족관계와 정신건강에 미치는 영향}

노인의 결혼지위 및 성별이 상호작용하여 가족관계, 정신건강에 미치는 영향을 파악하기 위해 이원분산분석을 실시하였다(표1 표6, 그림1 그림4).

\subsubsection{4년도 노인의 결혼지위와 성별이 가족관계에 미치는 영향}

노인의 결혼지위와 성별이 상호작용하여 2014년도 가족관계만족도, 가족갈등에 유의한 영향을 미쳤다. 가족관계만족도를 살펴보면, 결혼지위 $(\mathrm{F}=303.206, \mathrm{p}=.000)$ 와 성별 $(\mathrm{F}=4.428$, $\mathrm{p}=.035)$ 의 주효과, 결혼지위와 성별의 상호작용효과 $(\mathrm{F}=6.759, \mathrm{p}=.009)$ 가 유의하였다. 전반적으로 기혼노인이 이혼노인에 비해 가족관계만족도가 높은 가운데, 기혼노인은 남성이 여성에 비해, 이혼노인은 여성이 남성에 비해 가족관계만족도가 높았다(표1, 그림1). 가족갈등을 살펴보면, 기혼노인의 가족갈등도 결혼지위 $(\mathrm{F}=31.777, \mathrm{p}=.000)$ 와 성별 $(\mathrm{F}=12.555, \mathrm{p}=.000)$ 의 주효과, 결혼지위와 성별의 상호작용효과 $(\mathrm{F}=12.012, \mathrm{p}=.001)$ 도 
유의하였다. 전반적으로 기혼노인의 가족갈등이 이혼노인에 비해 높은 가운데, 기혼은 남녀 간의 차이가 별로 없으나, 이혼노인은 남성이 여성에 비해 가족갈등이 상당히 높았다(표 2, 그림 2).

[표 1] 노인의 결혼지위와 성별이 가족관계만족도에 미치는 영향 2014년도

[Table 1] The Influence of Elderly Marital Status and Gender on Family Relationship Satisfaction_2014year

\begin{tabular}{c|c|c|c|c}
\hline 소스 & 제 III 유형 제곱합 & 평균 제곱 & F & 유의확률 \\
\hline 수정 모형 & $112.763^{\mathrm{a}}$ & 37.588 & 102.322 & .000 \\
\hline 절편 & 10503.364 & 10503.364 & 28592.459 & .000 \\
\hline 결혼지위 & 111.382 & 111.382 & 303.206 & .000 \\
\hline 성별 & 1.626 & 1.626 & 4.428 & .035 \\
\hline 결혼지위*성별 & 2.483 & 2.483 & 6.759 & .009 \\
\hline 오차 & 1411.716 & .367 & & \\
\hline 합계 & 57063.000 & & & \\
\hline 수정 합계 & 1524.479 & & & \\
\hline
\end{tabular}

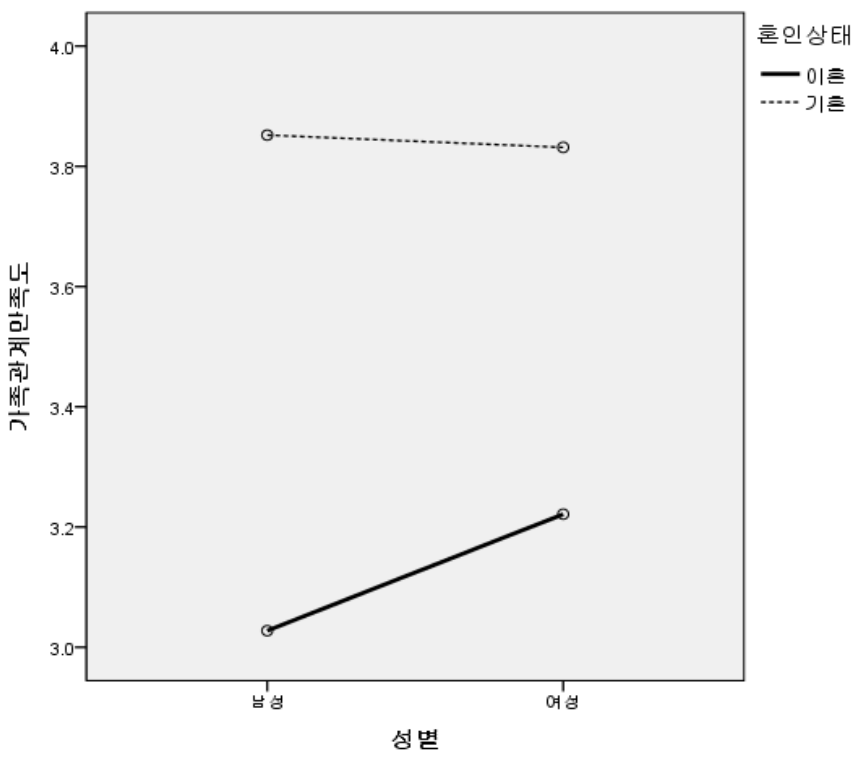

[그림 1] 노인의 결혼지위와 성별이 가족관계만족도에 미치는 영향 2014년도

[Fig. 1] The Influence of Elderly Marital Status and Gender on Family Relationship Satisfaction_2014year

[표 2] 노인의 결혼지위와 성별이 가족갈등에 미치는 영향_2014년도

[Table 2] The Influence of Elderly Marital Status and Gender on Family Conflict_2014year

\begin{tabular}{c|c|c|c|c|c}
\hline 소스 & 제 III 유형 제곱합 & 자유도 & 평균 제곱 & $\mathrm{F}$ & 유의확률 \\
\hline 수정 모형 & $13.509^{\mathrm{a}}$ & 3 & 4.503 & 15.676 & .000 \\
\hline 절편 & 2127.522 & 1 & 2127.522 & 7406.649 & .000 \\
\hline 결혼지위 & 9.128 & 1 & 9.128 & 31.777 & .000 \\
\hline 성별 & 3.606 & 1 & 3.606 & 12.555 & .000 \\
\hline
\end{tabular}




\begin{tabular}{c|c|c|c|c|c}
\hline 결혼지위*성별 & 3.450 & 1 & 3.450 & 12.012 & .001 \\
\hline 오차 & 1161.618 & 4044 & .287 & & \\
\hline 합계 & 12131.880 & 4048 & & & \\
\hline 수정 합계 & 1175.127 & 4047 & & & \\
\hline
\end{tabular}

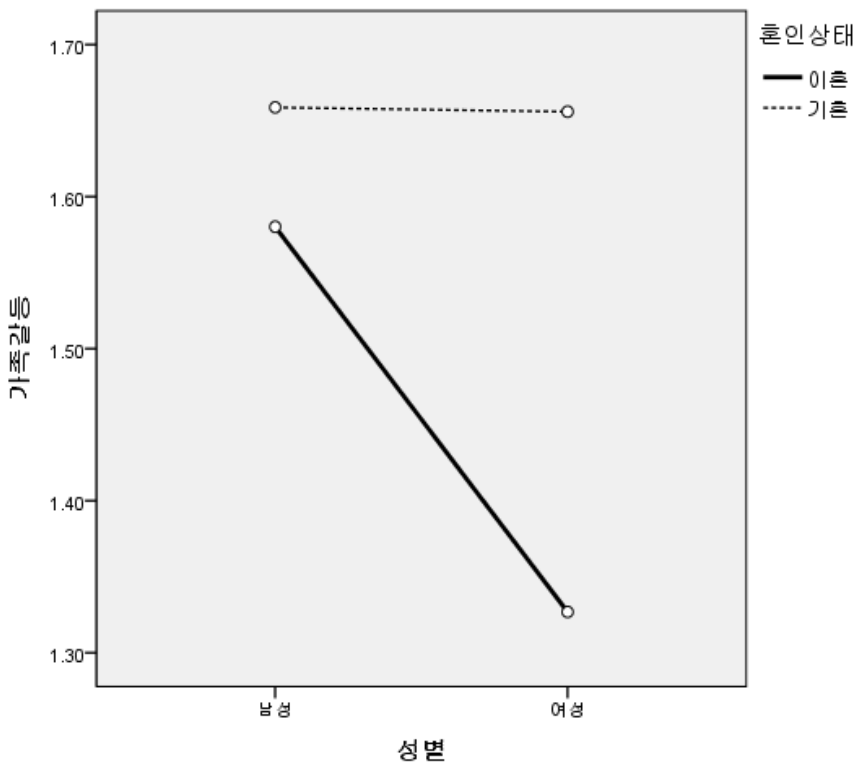

[그림 2] 노인의 결혼지위와 성별이 가족갈등에 미치는 영향_2014년도

[Fig. 2] The Influence of Elderly Marital Status and Gender on Family Conflict_2014year Page

\subsubsection{4년도 노인의 결혼지위와 성별이 정신건강에 미치는 영향}

노인의 결혼지위와 성별이 상호작용하여 2014년도 삶의 만족도, 우울감에 유의한 영향을 미쳤다. 삶의 만족도를 살펴보면, 결혼지위 $(\mathrm{F}=44.325, \mathrm{p}=.000)$ 와 성별 $(\mathrm{F}=5.341$, $\mathrm{p}=.021)$ 의 주효과, 결혼지위와 성별의 상호작용효과 $(\mathrm{F}=8.954, \mathrm{p}=.003)$ 가 유의하였다. 전반적으로 기혼노인이 이혼노인에 비해 삶의 만족도가 높은 가운데, 기혼노인은 남성이 여성에 비해, 이혼노인은 여성이 남성에 비해 삶의 만족도가 높았다(표3, 그림3). 우울감을 살펴보면, 결혼지위의 주효과 $(\mathrm{F}=72.092, \quad \mathrm{p}=.000)$ 와, 결혼지위와 성별의 상호작용효과 $(\mathrm{F}=3.962, \mathrm{p}=.047)$ 가 유의미하였고, 이혼노인의 우울감이 기혼노인에 비해 높았다. 기혼노인은 여성이 남성에 비해, 이혼노인은 남성이 여성에 비해 우울감이 높았다[표 4][그림 4].

[표 3] 노인의 결혼지위와 성별이 삶의 만족도에 미치는 영향_2014년도

[Table 3] The Influence of Elderly Marital Status and Gender on Life Satisfaction_2014year

\begin{tabular}{c|c|c|c|c|c}
\hline 소스 & 제 III 유형 제곱합 & 자유도 & 평균 제곱 & $\mathrm{F}$ & 유의확률 \\
\hline 수정 모형 & $22.682 \mathrm{a}$ & 3 & 7.561 & 17.388 & .000 \\
\hline 절편 & 9246.478 & 1 & 9246.478 & 21264.777 & .000 \\
\hline 결혼지위 & 19.274 & 1 & 19.274 & 44.325 & .000 \\
\hline 성별 & 2.322 & 1 & 2.322 & 5.341 & .021 \\
\hline 결혼지위*성별 & 3.893 & 1 & 3.893 & 8.954 & .003 \\
\hline
\end{tabular}




\begin{tabular}{c|c|c|c|c|c}
\hline 오차 & 1671.036 & 3843 & .435 & & \\
\hline 합계 & 46180.000 & 3847 & & & \\
\hline 수정 합계 & 1693.719 & 3846 & & & \\
\hline
\end{tabular}

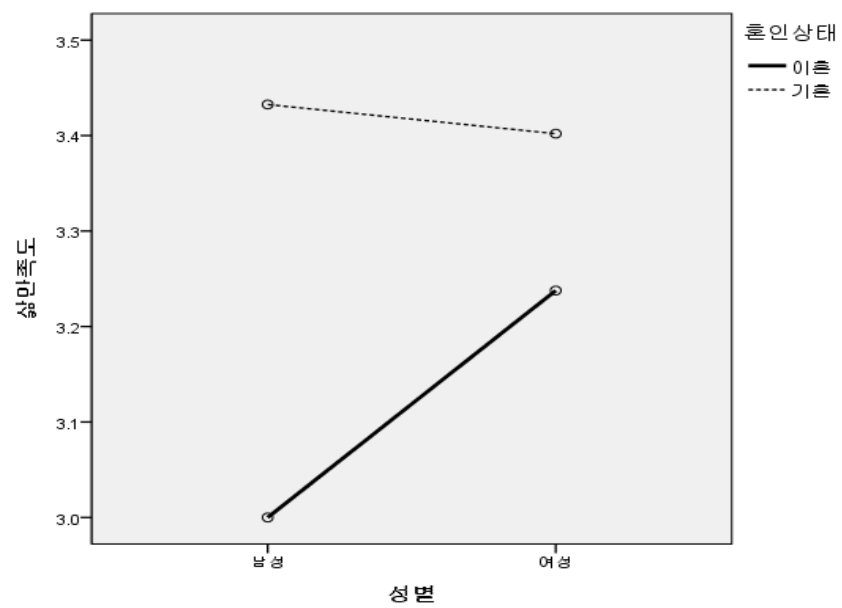

[그림 3] 노인의 결혼지위와 성별이 삶의 만족도에 미치는 영향_2014년도

[Fig. 3] The Influence of Elderly Marital Status and Gender on Life Satisfaction_2014year

[표 4] 노인의 결혼지위와 성별이 우울감에 미치는 영향_2014년도

[Table 4] The Influence of Elderly Marital Status and Gender on Depression_2014year

\begin{tabular}{c|c|c|c|c|c}
\hline 소스 & 제 III 유형 제곱합 & 자유도 & 평균 제곱 & F & 유의확률 \\
\hline 수정 모형 & $26.441^{\mathrm{a}}$ & 3 & 8.814 & 42.842 & .000 \\
\hline 절편 & 2161.029 & 1 & 2161.029 & 10504.479 & .000 \\
\hline 결혼지위 & 15.448 & 1 & 15.448 & 75.092 & .000 \\
\hline 성별 & .482 & 1 & .482 & 2.341 & .126 \\
\hline 결혼지위*성별 & .815 & 1 & .815 & 3.962 & .047 \\
\hline 오차 & 790.394 & 3842 & .206 & & \\
\hline 합계 & 9008.397 & 3846 & & & \\
\hline 수정 합계 & 816.834 & 3845 & & & \\
\hline
\end{tabular}

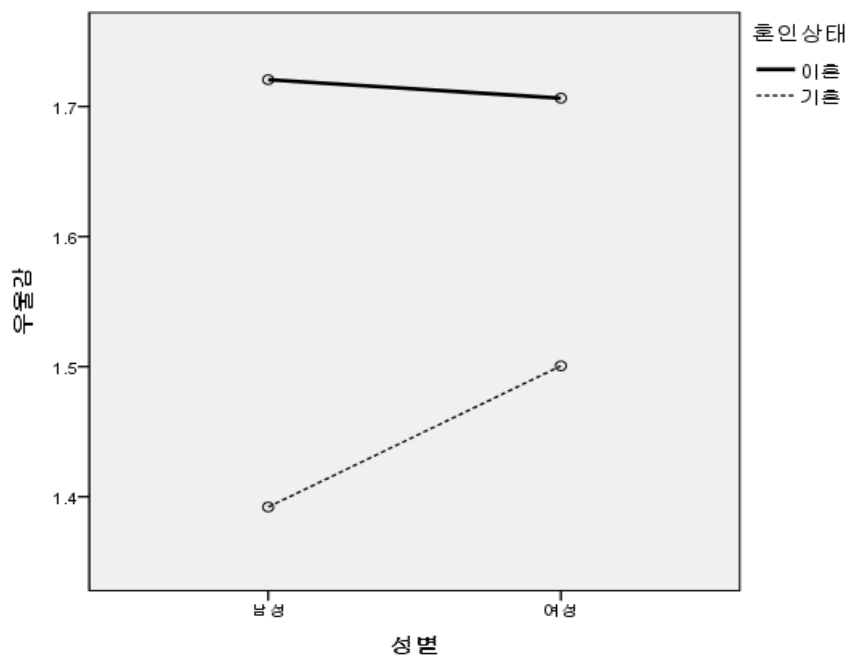


[그림 4] 노인의 결혼지위와 성별이 우울감에 미치는 영향_2014년도

[Fig. 4] The Influence of Elderly Marital Status and Gender on Depression_2014year

\subsection{9 년도 노년기 결혼지위와 성별이 가족관계와 정신건강에 미치는 영향}

\subsubsection{9년도 노인의 결혼지위와 성별이 가족관계에 미치는 영향}

노인의 결혼지위와 성별이 상호작용하여 2019년도 가족관계만족도에도 유의한 영향을 미쳤다. 결혼지위 $(\mathrm{F}=188.013, \mathrm{p}=.000)$ 와 성별 $(\mathrm{F}=6.002, \mathrm{p}=.014)$ 의 주효과, 결혼지위와 성별의 상호작용효과 $(\mathrm{F}=10.922, \mathrm{p}=.001)$ 가 유의하였다. 기혼노인의 가족관계만족도가 이혼노인에 비해 높은 가운데, 기혼노인은 남성이 여성에 비해, 이혼노인은 여성이 남성에 비해 가족관계만족도가 높았다(표5). 2014년도의 그림 1 과 같은 패턴이어서 그림을 제시하지 않았다. 한편, 노인의 결혼지위와 성별은 가족갈등에 유의한 영향을 미치지 않았다.

[표 5] 노인의 결혼지위와 성별이 가족관계만족도에 미치는 영향_2019년도

[Table 5] The Influence of Elderly Marital Status and Gender on Family Relationship Satisfaction_2019year

\begin{tabular}{c|c|c|c|c|c}
\hline 소스 & 제 III 유형 제곱합 & 자유도 & 평균 제곱 & F & 유의확률 \\
\hline 수정 모형 & $66.835^{\mathrm{a}}$ & 3 & 22.278 & 63.968 & .000 \\
\hline 절편 & 8253.816 & 1 & 8253.816 & 23699.349 & .000 \\
\hline 결혼지위 & 65.479 & 1 & 65.479 & 188.013 & .000 \\
\hline 성별 & 2.090 & 1 & 2.090 & 6.002 & .014 \\
\hline 결혼지위*성별 & 3.804 & 1 & 3.804 & 10.922 & .001 \\
\hline 오차 & 1069.891 & 3072 & .348 & & \\
\hline 합계 & 46434.000 & 3076 & & & \\
\hline 수정 합계 & 1136.726 & 3075 & & & \\
\hline
\end{tabular}

\subsubsection{9년도 노인의 결혼지위와 성별이 정신건강에 미치는 영향}

노인의 결혼지위와 성별이 상호작용하여 2019년도 삶의 만족도에도 유의한 영향을 미쳤다. 결혼지위의 주효과 $(\mathrm{F}=33.575, \mathrm{p}=.000)$ 와 결혼지위와 성별의 상호작용효과 $(\mathrm{F}=4.645$, $\mathrm{p}=.031)$ 가 유의한 가운데, 전반적으로 기혼노인의 삶의 만족도가 이혼노인에 비해 높았다. 기혼노인은 남성이 여성에 비해, 이혼노인은 여성이 남성에 비해 삶의 만족도가 높았다(표6). 2014년도의 그림 3과 같은 패턴이어서 그림을 제시하지 않았다. 한편, 노인의 결혼지위와 성별은 우울감에는 유의한 영향을 미치지 않았다.

[표 6] 노인의 결혼지위와 성별이 삶만족도에 미치는 영향 2019년도

[Table 6] The Influence of Elderly Marital Status and Gender on Life Satisfaction_2019year

\begin{tabular}{c|c|c|c|c|c}
\hline 소스 & 제 III 유형 제곱합 & 자유도 & 평균 제곱 & F & 유의확률 \\
\hline 수정 모형 & $13.801^{\mathrm{a}}$ & 3 & 4.600 & 11.993 & .000 \\
\hline 절편 & 7508.699 & 1 & 7508.699 & 19575.940 & .000 \\
\hline 결혼지위 & 12.878 & 1 & 12.878 & 33.575 & .000 \\
\hline 성별 & 1.009 & 1 & 1.009 & 2.630 & .105 \\
\hline 결혼지위*성별 & 1.782 & 1 & 1.782 & 4.645 & .031 \\
\hline
\end{tabular}




\begin{tabular}{c|c|c|c|c|c}
\hline 오차 & 1178.320 & 3072 & .384 & & \\
\hline 합계 & 39238.000 & 3076 & & & \\
\hline 수정 합계 & 1192.121 & 3075 & & & \\
\hline
\end{tabular}

\section{4. 논의}

첫째, 노년기 결혼지위는 2014년도와 2019년도 가족관계와 정신건강에 모두 유의한 영향을 미쳤다. 기혼노인이 이혼노인에 비해 가족관계만족도와 삶의 만족도가 높고, 우울감이 낮았다. 기혼노인이 이혼노인에 비해 삶의 여러 영역에서 긍정적이라는 것은 선행연구[1][6-8]와 같은 맥락이다. 이러한 결과는 결혼자원모델에서 기혼자가 이혼자에 비해 삶의 질이 높은 이유로 사회통제와 사회통합, 그리고 경제적 자원의 공유라는 측면에서 설명하였다[15]. 사회통제란 결혼을 통해 형성된 가족에 대한 애정과 관심, 책임감 등으로 자기 자신 뿐 아니라 배우자에게 안정된 삶의 양식을 취하게 하고 위험행동을 감소시키는 통제기능을 한다는 것을 의미한다[16]. 사회통합이란 결혼을 통해 배우자 및 더 큰 친족 관계망에 연계되며, 이를 통해 관계망 성원으로부터 다양한 사회적 지원을 얻게 된다는 것을 의미한다[17]. 마지막으로 경제적 자원의 공유는 결혼을 통해 공유하게 되는 경제적 자원이 기혼자들의 건강을 향상시키는데 영향을 미친다는 설명이다[8]. 이혼과 같은 결혼해체로 가족불안정 및 외로움, 고립감의 증폭이 노년기 정신건강에 부정적이라 할 수 있다[18].

그런데 가족갈등도 이혼노인에 비해 기혼노인이 더 높았다는 점에 주목할 필요가 있다. 이는 모든 결혼이 다 긍정적인 것은 아니며, 배우자와의 갈등이 건강에 부정적인 영향[15]을 미치기 때문이다. 즉, 이혼노인의 경우 배우자와의 갈등이라는 가족갈등의 중요 요소가 사라졌기 때문에 기혼노인에 비해 가족갈등이 낮다고 해석이 된다.

둘째, 결혼지위와 성별이 상호작용하여 2014년도 가족관계만족도와 가족갈등, 삶의 만족도와 우울감, 2019년도 가족관계만족도와 삶의 만족도에 유의한 영향을 미쳤다. 가족갈등을 제외하고, 결혼지위와 성별에 따른 4집단 중 이혼남성노인의 가족관계만족도와 삶의 만족도가 가장 낮고, 우울감은 가장 높았다. 이처럼 이혼남성의 삶의 질 수준이 낮은 것은 다음 몇 가지로 설명이 된다. 첫째는, 남성은 이혼으로 인해 이상적인 가정(전통적 가족주의 측면에서)을 지켜내지 못했다는 실패감을 크게 느끼며[18], 둘째, 남성은 여성보다 더 심하게 타인에게 이혼 사실을 감추거나 대인관계에서도 위축되는 모습을 보이며[9], 결혼이 주는 혜택을 남성이 더 많이 받기 때문에 이혼 후 남성이 여성에 비해 신체건강이 나쁘고[8][10] 이에 따라 이혼의 부정적 영향을 많이 받는다[19][20]는 점으로 해석이 가능하다. 따라서 노년기의 삶의 질을 향상시키기 위한 다양한 사업들은 이혼한 남성노인에게 우선적으로 제공될 필요가 있음을 제안한다.

셋째, 시간경과에 따라서 결혼지위와 성별이 가족관계 및 정신건강에 미치는 영향은 감소하고 있었다. 즉, 2014년도에는 가족관계만족도, 가족갈등, 삶의 만족도, 우울감 4개 영역에서 모두 결혼지위와 성별의 상호작용효과가 유의하였으나, 2019년도에는 가족관계만족도와 삶의 만족도에만 유의한 영향을 미쳤다. 즉 이혼 후 시간이 경과하면서 결혼이 주는 긍정적 부정적 효과, 성별에 따른 차이들이 좀 완화되고 있음을 알 수 있으며, 이는 이혼노인 만을 대상으로 하였으나 시간경과에 따라 성별 차이가 줄어든다는 김윤정[13] 연구결과를 뒷받침하고 있다. 이러한 시간경과에 따른 효과를 
이혼가족을 위한 사업에서 고려할 필요가 있다.

\section{5. 감사의 글}

이 논문은 2020년 대한민국 교육부와 한국연구재단의 인문사회분야 중견연구자 지원사업의 지원을 받아 수행된 연구임 (NRF-2020S1A5A2A01046650).

\section{References}

[1] M. A. Lee, Depression and Gender Differences in the Elderly According to Marital Status, Korean Journal of Sociology, (2010), Vol.44, No.4, pp.32-62, UCI: G704-000205.2010.44.4.003

[2] H. K. Kim, The Effect of Marital Conflict and Problem Drinking on Depression of the Elderly, Korea Society of Alchohol Science and Health Behavior, (2010), Vol.11, No.2, pp.95-106, UCI: G704-SER000008901.2010.11.2.008

[3] R. C. Atchley, Retirement and Marital Satisfaction, Sage Publications, (1992), (Families and Retirement), pp.145-158, DOI: https://doi.org/10.4135/9781483325354.n9

[4] K. S. Han, Analysis of Marital Conflict among the Elderly, Inha University, Master's Thesis, (2013)

[5] S. G. Seo, Y. H. Lee, J. S. Ahn, Y. S. Chong, An Exploratory Study on Perceived Conflict with Spouse and Adult Children of the Korean Elderly, Korean Journal of Psychology:General, (2013), Vol.32, No.2, pp.389-409, UCI: G704001037.2013.32.2.004

[6] R. B. Canady, C. Broman, Marital Disruption and Health: Investigating the Role of Divorce in Differential Outcomes, Sociological Focus, (2003), Vol.36, No.3, pp.241-255, DOI: https://doi.org/10.1080/00380237.2003.10570726

[7] Y. J. Kim, Panel Analysis on the Changes in the Quality of Life of the Divorced Elderly, Elementary Education Online, (2021), Vol.20, No.3, pp.1028-1034, DOI: 10.17051/ilkonline.2021.03.112

[8] E. K. Jang, H. J. Choi, Association between Divorce and Physical Health in Middle Age: Gender Difference in the Mediating Effect of Family/Social Relationship Satisfaction, Journal of Family Relations, (2019), Vol.24, No.1, pp.2343.

[9] J. K. Choi, K. H. Lee, Essence and Significance of Life-World Experience of Fathers from Divorced Low-income Single Parent Families, Korean Journal of Qualitative Research in Social Welfare, (2015), Vol.9, No.2, pp.5-30, DOI: 10.22867/kaqsw.2015.9.2.5

[10] A. Ikeda, H. Iso, H. Toyoshima, Y. Fujino, T. Mizoue, T. Yoshimura, Y. Inaba, A. Tamakoshi, Marital Status and Mortality among Japanese Men and Women: The Japan Collaborative Cohort Study, BMC Public Health, (2007), Vol.7, No.1, pp.73-80, DOI: 10.1186/1471-2458-7-73

[11] S. J. Park, Changes in Suicide Rate According to Marital Status: Focusing on Gender Differences, Mental Health Policy Forum, (2010), Vol.4, No.1, pp.125-137.

[12] M. Gray, D. de Vaus, L. Qu, D. Stanton, Divorce and the Wellbeing of Older Australians, Ageing \& Society, (2011), Vol.31, No.3, pp.475-498, DOI: https://doi.org/10.1017/S0144686X10001017

[13] Y. J. Kim, Changes in Adaptation after Divorce over Time among Korean Older Adults: Focusing on Sex Differences, Journal of Korean Gerontological Nursing, (2021), Vol.23, No.2, pp.129-139, DOI: 10.17079/jkgn.2021.23.2.129

[14] Korea Welfare Pannel Study, Survey design, https://www.koweps.re.kr:442/main.do, Feb 5 (2021)

[15] G. H. Han, H. K. Choi, J. S. Ahn, J. H. Kim, The Gerontology, Shinjung Publishers, (2019).

[16] D, Umberson, K. Williams, D. A. Powers, H. Liu, B. Needham, You Make Me Sick: Marital Quality and Health over the Life Course, Journal of Health and Social Behavior, (2004), Vol.47, No.1, pp.1-16, DOI: 
$10.1177 / 002214650604700101$

[17] K. Williams, D. Umberson, Marital Status, Marital Transitions, and Health: A Gendered Life Course Perspective, Journal of Health and Social behavior, (2004), Vol.45, No.1, pp.81-98, DOI: 10.1177/002214650404500106

[18] C. Deborah, Gender, Preloss Marital Dependence, and Older Adults' Adjustment to Widowhood, Journal of Marriage and Family, (2004), Vol.66, No.1, pp.220-235, DOI: https://doi.org/10.1111/j.0022-2445.2004.00016.x

[19] S. N. Kim, Gendered Narratives in Post-divorce: Women's and Men's Experiences of Loss and the Meaning of New Relationships, Journal of Korean Women's Studies, (2009), Vol.25, No.4, pp.41-72, UCI: G704-000349.2009.25.4.001

[20] E. Shor, D. J. Roelfs, P. Bugyi, J. E. Schwartz, Meta-analysis of Marital Dissolution and Mortality: Reevaluating the Intersection of Gender and Age, Social Science \& Medicine, (2012), Vol.75, No.1, pp.46-59, DOI: 10.1016/j.socscimed.2012.03.010 